\title{
The Study of Self-employment at SMEs Level with Reference to Poverty in Developing Countries
}

\author{
Muhammad Nawaz Tunio ${ }^{1}$, Aqeel Ahmed Soomro ${ }^{2} \&$ Dieter Bögenhold ${ }^{1}$ \\ ${ }^{1}$ Department of Sociology, University of Klagenfurt, Austria \\ ${ }^{2}$ Department of Innovation Management and Entrepreneurship, University of Klagenfurt, Austria \\ Correspondence: Muhammad Nawaz Tunio, Department of Sociology, University of Klagenfurt, Austria
}

Received: March 28, 2017

Accepted: April 13, 2017

Online Published: April 23, 2017

doi:10.5430/bmr.v6n2p33

URL: https://doi.org/10.5430/bmr.v6n2p33

\begin{abstract}
This study endeavors to answer the research question; how self-employment at Small and Medium Enterprises (SMEs) level is related to poverty in the developing countries. During these efforts, we used the narrative literature review, methodology, to study related research stream in this domain to develop a better understanding of the phenomenon. Moreover, in the process Peter Ducker and Noel's theory of entrepreneurship and Israel Kirzner's theory of entrepreneurship reviewed to develop theoretical foundations of our research. In this research, we come to the observation that self-employment at SMEs level, somehow helps in fighting poverty in the developing countries. In addition, interestingly Information and Communication Technology (ICT) role has been significant in the developing countries from the context of gig economy, where the firms might not be found in yellow pages, but yet they are part of the economic system against poverty (Subrahmany, 2005).
\end{abstract}

Keywords: Self-employment, SMEs, Poverty and ICT

\section{Introduction}

It is bitter, but a reality that poor/developing countries have limited resources. Thus, unequal distribution of wealth always remains a heated debate within and among nations. However, this study does not explore factors that cause unequal distribution of wealth. Rather, this research highlights self-employment at the SMEs level role that can help to reduce the economic problems in the developing countries within the existing economic setup. Since the poor countries have limited resources, thus common people do not have much of their livelihood and very less options for employment (Acs, 2006). In such a scenario with ever increasing population in developing countries, every next day further aggravates this situation (Kelley and Schmidt, 1995). This deteriorating situation adversely affects population in the developing world. In order to find an appropriate solution, self-employment can be an effective technique to engage people in the labor market and to reduce poverty (Langevang and Gough, 2012). In this connection, self-employment at SMEs level can help somehow in solving problems in the developing countries. Self-employment at SMEs level refers to small businesses, which can be started with a small amount of capital and less number of employees, often without any employee at all (Abor and Quartey, 2010). Success of Grameen bank in Bangladesh in the field of SMEs is an example of how the term self-employment can bring prosperity in a developing country (Dowla, 2006). Realizing the need of such small self-employed businesses in the developing countries, this study conducts literature reviews to develop a better understanding of the phenomenon for future research in this area. Thus, this study may contribute to define the relation of poverty via self-employment at the small and medium level businesses. In this connection, Peter Drucker and Noel's (1986) theory, Israel Kirzner's (2009) theory and Shane and Vankataraman's (2000) framework for entrepreneurship are used as the theoretical foundations to develop in depth understanding of the term self-employment with reference to poverty.

\subsection{Relationship between Self-employment and Poverty}

Scarcity of resources is increasing due to increase in the world's population (Schumpeter, 1934) and the effect is severe in the developing countries. Hence, the situation calls for research in developing countries to meet the increasing population needs. In this regard number of factors are already under research, which arises due to economic problems (Samuelson and Nordhaus, 1998) and poverty is a paramount among them (Hallsten, et al., 2017). Poverty has adversely affected populations due to social and economic constraints (Bhattacharyaa and Londheb, 2014) and it is a collective problem of society (Lim, et al., 2016). Status of economically deprived person 
is a social devastation that drives many problems (Bruton, et al., 2013). Hence, economic deprivation is one of those problems that occur due to poverty, which causes frustration among the people. This situation is an output of economic fluctuations that negatively affect the livelihood of the masses (Hesham and McCoya, 2014). From local to international level, economic crises are a major concern for every developing country. Thus, the state and the institutions of such countries always react enthusiastically to all those options, which can bring economic prosperity. In such situation, self-employment could be a good technique to deal with economic problems. The need of self-employment has remained a hot issue even in classical, social and economic research (Schumpeter, 1934; Schumpeter, 1942). There are several threats and opportunities that affect the functionality of self-employment or the renowned term as entrepreneurship (Shane and Vankataraman, 2000). While going through a positive approach, besides many other aspects, "self-employment at SMEs level" is one of the important factors that help economic growth particularly in the developing countries (Verrest, 2013).

Self-employment is an instrument to control the economic crises, to reduce the poverty and has a prominent contribution in socioeconomic development of local economy of developing countries (Spence and Elliot, 2012). In situations, where resources are scarce, self-employment at SMEs level can play a key role. Self-employment at SMEs level is a multi-dynamic activity at small level that can bring prosperity at large in the society in the shape of improved living standards of the masses (Narula, et al., 2016). Beginning of self-employment at SMEs level has come under focus for many reasons in developed and developing countries. It has created alternatives of engaging potential people individually or in groups in productive activities for the collective benefits of a society (Vial and Hanoteau, 2015), which in result influences poverty (Yanya, et al., 2013).

Moreover, ICT has created new options and opportunities of electric self-employment at SMEs level at lower investments in developing countries. For example, Bangalore (India), which is the hub of self-employment at SMEs level in ICT, where inventions and innovations are carried out by individuals at a small level in order to produce the products and services via development of need based software which are supplied within and among countries via ICT (Subrahmany, 2005). It has paved a new way to the future economy. Besides this, mobile communication services start with the self-employers at the SMEs level to renovate mobiles and install software (Donner and Escobari, 2010). The introduction of the internet in many current business aspects has changed the practices and procedures and the traditional economy is moving towards the gig economy concept. Where, the workers in the business might not be full time or permanent employees or the firms in the business would not be found in the yellow pages but, still they have their important part of the overall economy. In case of self-employment at SMEs level, new technologies have widened its scope (Castells, 2010). As a consequence, technology has embarked a new form of self-employment at SMEs level, where new opportunities have been created by the experts, consultants, and promoters of products and services (Jelonek, 2015).

In this context, being in a competitive age, merger of new technologies has reshaped every process (Castells, 2010). ICT is promoting self-employment at SMEs level engaged in the ICT applications, products or electronic markets from traditional entrepreneurship (Saga, et al., 2016). Emerging technologies are much valued in social perspectives (Tunio, et al., 2013) $)^{3}$. ICT for commercial purpose drive innovation and increases channels from local markets to international markets (Narula, 2004). Absorption of technological capability in services leads to new priorities in business (Rothwell (1991). As a study in Austria, Belgium, Denmark and Norway, disclosed influence of ICT on practices in business (Ebersberger et al., 2010) while, Vahter et al. (2014) showed that ICT is most crucial to self-employment at the SMEs level of innovation. Tunio, et al. (2014) ${ }^{4}$ mentioned that the use of ICT is increasing in urban areas of Pakistan. Thus, based on the findings from existing literature, it will be interesting to study, self-employment at SMEs level with reference to poverty.

\section{Theoretical Framework}

Self-employment/Entrepreneurship is among the hot topics of today's research (McDougall and Oviat, 2000). In this connection, many theories have been proposed to explain this phenomenon. As Peter Drucker and Noel (1986) discussed in their theory of entrepreneurship that entrepreneurship is a novel source of employment to combat with poverty by production of goods and services in order to improve the social and economic status of society. This entrepreneurial approach adopts innovation to engage people in productive activities. While, theory of entrepreneurship proposed by Israel Kirzner (2009) describes that entrepreneurship is an independent process of alertness to explore and exploit resources to create a new environment for the employment of youth. However, Shane and Vankataraman (2000) articulate that entrepreneurial opportunities nurture in the environment, where there is tendency to exploit the resources and create a new mechanism for the societies to create goods and services with the help of emerging technologies. 


\subsection{Observations Drawn from the Literature}

The rise of poverty is one among the indicators of economic crises (Ghoshray, et al., 2016), hence, poverty is a worldwide economic issue in the developing countries (Murtin and Robin, 2016). This issue is driven by the expansion of population, as an increasing population order causes competition in employment and leaves many people unemployed due to either limited opportunities or lack of skills/competence which results in poverty (Nolen, 2013). Poverty adversely affects the abilities and skills of youth by reducing their opportunities to earn from the available sources (Agnelloa, et al., 2014) and the physical health by creating stress and anxiety, such deterioration is a prone to ill health to the deprived population (Heggebo, 2015). Besides this, there are many other negative implications of poverty that can vary from country to country. Jallade (1987) exposed contextual reasons of poverty, such as economic collapse of employment opportunities, education level, experience, skills, attitude, religion and family structure. Lee and Parasni (2014) showed that the involvement of maximum workforce causes unemployment which further increases poverty problems. Osmana, et al. (2015) explored the induction of employee from foreign countries reduces the opportunities in the indigenous market and creates an unstable situation for the local people. Bhorat, (2007) found that due to higher education, there may be a possibility of more employment opportunities in the job market, but poor education in developing countries is another reason towards the poverty. Tunio, et al. (2013) yield that organizations demanding qualification and rich experiences for low educates or fresh graduates are barriers of entry to job in Pakistan.

Emanuelaa and Cirnua (2014) defined urban-rural led to decrease in opportunities for the inhabitants. Miocene and Jouzaryanb (2016) examined the inflation that negatively affects economic conditions in the low income countries. Whereas, firms always plan to create limited opportunities against a great pool of population and invite them to enter in competition, so that efficient staff can be hired in order to improve work efficiency of a firm and better productivity. On the other side, it leaves less opportunities for the people expecting to combat poverty. In the competitive race, complicated legislation on the employment protection affects insurance and incentives of employees (Cahuc, 2014). In order to find the solution to reduce poverty, Baptista and Thurik (2007) identified that during the last decade, self-employment at SMEs level has got a momentum and called the attention of many institutions and individuals. García and Santiso (2017) found that unemployment is the cause of social distress and the active role of social and corporate organizations can promote the self employment in Spain.

Self-employment is a phenomenon about availability of opportunities and innovative persons to take initiatives to exploit these opportunities. As exploitation of available opportunities is subject to many prerequisites, like information, raw material and services to start a new business. Thus, opportunities may be found in product market or factor market. Moreover, availability of innovative persons is equally paramount in this process, who use their skills, experience and knowledge to start and maintain new businesses successfully (Shane and Vankataraman, 2000). In addition, Self-employment at SMEs level is a sub category of self-employment that deals with the businesses, and exploitation of resources at smaller levels. This form of self-employment can be more productive for the countries, where there are limited resources. In such a situation, self-employment at SMEs level could be a good option to convert adverse circumstances into prosperity (Honig, 1998). People of developing countries can take advantage from self-employment at SMEs level by starting a business at low investment. If in case, such peoples start that business on the small loans or investments, with time, when they repay their loans, they may have small and medium assets, and then they have got the platform to further expand their businesses (Vial and Hanoteau, 2015).

Therefore, we observed that self-employment at SMEs level somehow helps in poverty reduction.

Cyber self-employment is a novel concept of the merger of the internet and entrepreneurship. Carrier, et al. (2004) mentioned cyber self-employment as a business with a new process to create new commercial opportunities. Self-employment at SMEs level requires compound resources, where ICT is a new approach to create something new. Ramsey and Ibbotson (2005) found that the internet provides a global perspective to a self-employment at SMEs level and (Floyd and Wooldridge, 1999) increases organizational capacity of self-employment. Online shopping is a platform for local producers to sell their products (Dess, et al., 1999). Self-employment at SMEs level is breeding in low income countries on account of ICT to foster new services and products. There are many real examples in the developing world, for instance, Bangladesh and India that how ICT promoted self-employment at the SMEs level in products and services nationally and internationally. ICT provides new survival to the micro entrepreneurship in Brazil, by creating opportunities through innovation (Russo, 2014). ICT practice is common in urban areas of India, where ICT offers an environment to poor people for self-employment with the help of technologies (Rangaswamya and Nairobi, 2012). Wamuyu (2015) Witnessed in Kenya, absorption of ICT furnishes a new platform for self-employment at the SMEs level to maximize profits with minor investment. Tunio, et al. $(2013)^{2}$ explored that 
ICT is multitasking in nature and hence, it is diffused in every service, including the education system as well.

Therefore, we observed that self-employment at SMEs level via ICT can help in poverty alleviation in the developing countries.

\section{Conclusion}

In this research, we have endeavored to highlight self-employment in developing countries with its observed outcomes on poverty. The majority of self-employed people is engaged in small and smallest firms which are run as one-(wo)men-firms without further employees, only a few self-employed business men serve as employers who have further employees in their firms. But totally, the vast majority of self-employed people fall into the area of SMEs. Of course, many forms of self-employment are in themselves a reaction to poverty and insufficient social and economic conditions. That means that many independent activities as businessmen are necessity driven (Kelley, 2015/2016), they are pushed by negative labor market data and missing alternatives in a formal labor market. Additionally, there is a very broad informal sector which does not really show up when looking just at sterile labor market statistics, where people engage in various forms of self-employment without being officially registered or recognized as businessmen. However, we don't want to see only those shadow sides of development, but we identify positive elements, especially in combination with the rise of new markets, occupational profiles and ways of education related to the ICT sector (Tunio, et al., 2013) ${ }^{5}$, which give us hope that self-employment and SMEs may also be seen as a tactical resource for further development with high impacts for (positive) regional survival and evolution. Looking at challenges, all new forms of decentralized, independent units of economic activity may have benefits for individual actors, especially also for many new forms of female participation in self-employment, and for the economy and society as a whole. All research in regional economics and related ideas on the "microeconomics of prosperity" (Porter, 2000) indicate this way of thought. Michael E. Porter (1990) argues that it is more reasonable to compare regions instead of referring to aggregate economies and their aggregate data. Regions are the core subject of socio - economic analysis. "Microeconomics of prosperity" (Porter, 2000) serves as a research program. Nowadays discussion on growth and regional policies often claims the need to foster clusters, a discussion which is based upon a perspective spread by Porter. We hope, this research will provide starting point for the fellow researchers to further study, self-employment at SMEs levels within the proposed economic lens for the developing countries. In this research, we have observed that; 1) self-employment at SMEs level somehow helps in poverty reduction and 2) self-employment at SMEs level via ICT can help in poverty alleviation in the developing countries.

\section{References}

Abor J. \& Quartey, P. (2010). Issues in SME Development in Ghana and South Africa. International Research Journal of Finance and Economics, ISSN 1450-2887 Issue 39.

Acs, Z. (2006). How Is Entrepreneurship Good for Economic Growth? Innovations, 97-107. Retrieved on 22-12-2016 from http://www.mitpressjournals.org/doi/pdf/10.1162/itgg.2006.1.1.97

Agnelloa L., Castro, V., Jalles, J. T., \& Sousa, R. M. (2014). Fiscal adjustments, labour market flexibility and unemployment. Economics Letters, 124, 231-235. https://doi.org/10.1016/j.econlet.2014.05.029

Babbitt, L. G., Brown, D., \& Mazaheri, N. (2015). Gender, Entrepreneurship, and the Formal-Informal Dilemma: Evidence from Indonesia. World Development, 72, 163-174. https://doi.org/10.1016/j.worlddev.2015.02.019

Baptista, R. \& Thurik, A. R. (2007). The relationship between entrepreneurship and unemployment: Is Portugal an outlier? Technological Forecasting and Social Change, $74, \quad 75 \quad-\quad 89$. https://doi.org/10.1016/j.techfore.2006.04.003

Berger, E. S. C. \& Kuckertz, A. (2016). Female entrepreneurship in startup ecosystems worldwide. Journal of Business Research, 69, 5163-5168. https://doi.org/10.1016/j.jbusres.2016.04.098

Bhattacharyaa, S. \& Londheb, B. R. (2014). Micro Entrepreneurship: Sources of Finance and Related Constraints. Procedia Economics and Finance, 11, 775 - 783. https://doi.org/10.1016/S2212-5671(14)00241-X

Bhorat, H. (2007). Unemployment in South Africa: Descriptors and determinants. Paper Presented to the Commission on Growth and Development, World Bank, Washington DC.

Bruton, G. D., Ketchen J. D. J., \& Ireland, R. D. (2013). Entrepreneurship as a solution to poverty. Journal of Business Venturing, 28, 683-689. https://doi.org/10.1016/j.jbusvent.2013.05.002

Burns, N., \& Grove, S. K. (2005). The Practice of Nursing Research: Conduct, Critique, and Utilization (5th Ed.). St. Louis, Elsevier Saunders. 
Cahuc, P. (2014). Search, flows, job creations and destructions. Labour Economics, 30, 22-29. https://doi.org/10.1016/j.labeco.2014.06.004

Carrier C., Raymond, L., \& Eltaief, A. (2004). Cyberentrepreneurship. A multiple case study. International Journal of Entrepreneurial Behaviour and Research, 10(5), 349-363. https://doi.org/10.1108/13552550410554320

Castells, M. (2010). The Rise of the Network Society. (2nd ed.). John Wiley \& Sons, Ltd.

Dess, G. G., Lumpkin, G. T., \& McGee, J. E. (1999). Linking corporate entrepreneurship to strategy, structure, and process: Suggested research directions. Entrepreneurship Theory and Practice, 23, 85-103.

Donner, J., \& Escobari, M. X. (2010). A review of evidence on mobile use by micro and small enterprises in developing countries. Journal of International Development, 22(5), 641-658. https://doi.org/10.1002/jid.1717

Dowla, A. (2006). In credit we trust: Building social capital by Grameen Bank in Bangladesh. The Journal of Socio-Economics, 35(1), 102-122. https://doi.org/10.1016/j.socec.2005.12.006

Drucker P. F. \& Noel, J. L. (1986). Innovation and Entrepreneurship: Practices and Principles. The Journal of Continuing Higher Education, 34(1). Published online: 05 Oct 2011.

Ebersberger B., Marsili O., Reichstein T. \& Salter A. (2010). Into thin air:using a quantile regression approach to explore the relationship between $\mathrm{R} \& \mathrm{D}$ and innovation. International Review of Applied Economics, 24(1), 95-102. https://doi.org/10.1080/02692170903424448

Emanuelaa, D. D., \& Cirnua, D. (2014). Unemployment Duration in Rural Romania. Economics and Finance, 15, $1173-1184$.

Floyd, S. W., \& Wooldridge, B. (1999). Knowledge creation and social networks in corporate entrepreneurship: The renewal of organizational capability. Entrepreneurship Theory and Practice, 23, 123-144.

García, M. R. \& -Santiso, V. M. (2017). Business-Led Social Innovation in the Work Integration Field: The Role of Large Firms and Corporate Foundations. Business and Management Research, 6(1).

Ghoshray, A., Ordóñez, J., \& Sala, H. (2016). Euro, crisis and unemployment: Youth patterns, youth policies? Economic Modelling, 58, 442-453. https://doi.org/10.1016/j.econmod.2016.05.017

Hallsten, M., Edling, C., \& Rydgren, J. (2017). Social capital, friendship networks, and youth unemployment. Social Science Research, 61, 234-250. https://doi.org/10.1016/j.ssresearch.2016.06.017

Heggebo, K. (2015). Unemployment in Scandinavian during an economic crisis: Cross-national differences in health selection. Social Science and Medicine, 130, 115-124. https://doi.org/10.1016/j.socscimed.2015.02.010

Hesham, A. E. M. \& McCoya, M. P. (2014). Entrepreneurship in Oman: Paving the way for a Sustainable Future. Economics and Finance, 15, $1632-1640$.

Honig, B. (1998). What determines success? Examining the human, financial, and social capital of Jamaican Micro entrepreneur. Journal of Business Venturing, 13, 371-394. https://doi.org/10.1016/S0883-9026(97)00036-0

Jallade, J-P. (1987). Youth Unemployment and Education. In Economics of Education. Research and Studies. (Ed.) Psacharopoulos, G. T. The World Bank, Pergamon Press. https://doi.org/10.1016/b978-0-08-033379-3.50033-4

Jelonek, D. (2015). The Role of Open Innovations in the Development of e-Entrepreneurship. Computer Science, 65, 1013 - 1022. https://doi.org/10.1016/j.procs.2015.09.058

Kelley, D., Singer, S., \& Herrington, M. (2015/16). GEM, Global Entrepreneurship Monitor. Global Report, download at: http://www.gemconsortium.org/report.

Kelleher, W. (1999). Storey: Writing History: A guide for Students. New York, NY: Oxford University Press).

Kelley, A. C. \& Schmidt, R. M. (1995). Aggregate population and economic growth correlations: The role of the components of demographic change. Demography, 32(4), 543-555. https://doi.org/10.2307/2061674

Kimbu, A. N. \& Ngoasong, M. Z. (2016). Women as vectors of social entrepreneurship. Annals of Tourism Research, 60, 63-79. https://doi.org/10.1016/j.annals.2016.06.002

Kirzner, I. M. (2009). The alert and creative entrepreneur: a clarification. Small Business Economics, 32(2), 145-152. https://doi.org/10.1007/s11187-008-9153-7

Langevang, T. \& Gough, K. V. (2012). Diverging pathways: young female employment and entrepreneurship in sub-Saharan Africa, 178(3), 242-252. https://doi.org/10.1111/j.1475-4959.2011.00457.x 
Lee, G. H. Y., \& Parasni, J. (2014). Discouraged workers in developed countries and added workers in developing countries? Unemployment rate and labour force participation. Economic Modelling, 41, 90-98. https://doi.org/10.1016/j.econmod.2014.04.005

Lim, D. S. K., Oh, C. H., \& Clercq, D. D. (2016). Engagement in entrepreneurship in emerging economies: Interactive effects of individual-level factors and institutional conditions. International Business Review, 25, 933-945. https://doi.org/10.1016/j.ibusrev.2015.12.001

McDougall, P. P. \& Oviatt, B. M. (2000). International Entrepreneurship: The Intersection of Two Research Paths. ACAD MANAGE J, 43(5), 902-906. https://doi.org/10.2307/1556418

Mohsenia, M., \& Jouzaryanb F. (2016). Examining the Effects of Inflation and Unemployment on Economic Growth in Iran (1996-2012). Economics and Finance, 36, 381-389. https://doi.org/10.1016/s2212-5671(16)30050-8

Murtin, F., \& Robin, J. M. (2015). Labor market reforms and unemployment dynamics. Labour Economics xxx (2016) $\quad \mathrm{xxx}-\mathrm{xxx}$. Retrieved on $05-12-2016$ from: http://ac.els-cdn.com/S0927537116300458/1-s2.0-S0927537116300458-main.pdf?_tid=a36d32e4-ba7b-11e6-ad 4b-00000aab0f26\&acdnat=1480895267_5d290fc36707c39dd9149d275f849e94

Nolen, P. (2013). Unemployment and household values: Distribution sensitive measures of unemployment. Labour Economics, 24, 354-362. https://doi.org/10.1016/j.labeco.2012.07.008

Osmana, M. M., Bachoka, S., Muslima, S. A., \& Bakri, N. I. M. (2015). Unemployment Issues and Problems in Kinta, Manjung and Kuala Kangsar, Perak, Malaysia. Procedia - Social and Behavioral Sciences, 168, 389 399. https://doi.org/10.1016/j.sbspro.2014.10.245

Porter, M. E (2000). Attitudes, Values, Beliefs, and the Microeconomics of Prosperity. In Culture Matters. How Values Shape Human Progress, eds. Lawrence E. Harrison and Samuel P. Huntington, New York: Basic Books, 14-27.

Pope, C., \& Mays, N. (1995). Qualitative Research: Reaching the parts other methods cannot reach: an introduction to qualitative methods in health and health services research. British Medical Journal, 311, 42-45. https://doi.org/10.1136/bmj.311.6996.42

Ramsey E., \& Ibbotson P. (2005). 'E' entrepreneurial SMEs: An Irish study of micro and macro influences. Journal of International Entrepreneurship, 3(4), 317-332. https://doi.org/10.1007/s10843-006-7859-7

Rangaswamya, N. \& Nairb, S. (2012). The PC in an Indian urban slum: enterprise and entrepreneurship in ICT4D 2.0. Information Technology for Development, 18(2), 163 -180. https://doi.org/10.1080/02681102.2011.643211

Rothwell, R. (1991). External networking and innovation in small and medium-sized manufacturing firms in Europe. Technovation, 11(2), 93-112. https://doi.org/10.1016/0166-4972(91)90040-B

Russo, L. (2014). Factors Conditioning Failure of Micro and Small Businesses of the Information Technology and Communication (ICT): Study of Multiple Cases, Aracaju (SE), Brazil. Business Management Dynamics, 3(8), 40-50.

Saga, S., Sezena, B., \& Güzela, M. (2016). Factors That Motivate or Prevent Adoption of Open Innovation by SMEs in Developing Countries and Policy Suggestions. Procedia - Social and Behavioral Sciences, 235, 756 - 763. https://doi.org/10.1016/j.sbspro.2016.11.077

Samuelson, P. A. \& Nordhaus, W. D. (1998). Economics, 16th edition, N.Y. at al.: McGraw-Hill.

Schumpeter, J. E. (1934). The theory of economic development. Transaction Publishers. New Brunswick (U.S.A) and London (U.K). Introduction by John E. Elliott (2004).

Schumpeter, J. E. (1942). Capitalism, socialism, and democracy. Teller \& Francis Group. London and New York. Introduction by Swedberg, R. (2000).

Shane, S. \& Vankataraman, S. (2000). The promise of Entrepreneurship as a field of research. Academy of Management Review, 25(1), 217-226. https://doi.org/10.5465/amr.2000.2791611

Spence, B. D. \& Elliot, E. A. (2012). African microentrepreneurship: The reality of everyday challenges. Journal of Business Research, 65, 1665-1673. https://doi.org/10.1016/j.jbusres.2012.02.007

Subrahmany, M. H. B. (2005). Pattern of technological innovations in small enterprises: a comparative perspective of Bangalore (India) and Northeast England (UK). Technovation, 25(3), 269-280. https://doi.org/10.1016/s0166-4972(03)00094-4 
Tunio, M. N., Sartaj, S. \& Abro, Q. M. M (2013) ${ }^{1}$. Strength-weakness-opportunity-threat [SWOT] analysis for the career development of new generation in Pakistan. European journal of business and management, 5(15).

Tunio, M. N., Abro, Q. M. M \& Rashdi, P. I. S. (2013)². Significance of public priorities from telecommunication to cellular communication in Pakistan. Journal of information engineering and applications, 3(10). ISSN 2224-5782 (print) ISSN 2225-0506 (online).

Tunio, M. N., Rashdi, P. I. S., Abro, Q. M. M \& Tunio, S. P. (2013) ${ }^{3}$. Social Impact of Virtual Communication on Nascent Society of Pakistan. IOSR Journal Of Humanities And Social Science (IOSR-JHSS), 10(5), 68-74. e-ISSN: 2279-0837, p-ISSN: 2279-0845.

Tunio, M. N., Rashdi, P. I. S. \& Abro, Q. M. M (2014)4. Evaluation of ICT Education in Private Secondary Schools: A Case Study of Hyderabad, Sindh. Mehran University Research Journal of Engineering \& Technology, 33(1).

Tunio, M. N., Arain, N. R. \& Tunio, S. P. (2013) $)^{5}$. Assessment of Computer Literacy at Secondary Education Level in Rural Areas of Sindh (Pakistan). International Journal of Emerging Science and Engineering (IJESE), 1(7).

Vahter, P., Love, J. H., \& Roper, S. (2014). Openness and innovation performance: are small firms different? Industry and Innovation, 21(7-8), 553-573. https://doi.org/10.1080/13662716.2015.1012825

Verrest, H. (2013). Rethinking Microentrepreneurship and Business Development Programs: Vulnerability and Ambition in Low-income Urban Caribbean Households. World Development, 47, 58-70. https://doi.org/10.1016/j.worlddev.2013.02.016

Vial, V. \& Hanoteau, J. (2015). Returns to Micro-Entrepreneurship in an Emerging Economy: A Quantile Study of Entrepreneurial Indonesian Households' Welfare. World Development, 74, 142-157. https://doi.org/10.1016/j.worlddev.2015.04.008

Wamuyu, P. K. (2015). The Impact of Information and Communication Technology Adoption and Diffusion on Technology Entrepreneurship in Developing Countries: The Case of Kenya. Information Technology for Development, 21(2), 253-280. https://doi.org/10.1080/02681102.2014.948372

Yanya, M., Hakim, R. A., \& Razak, N. A. A. (2013). Does entrepreneurship bring an equal society and alleviate poverty? Evidence from Thailand. Social and Behavioral Sciences, 91, 331 - 340. https://doi.org/10.1016/j.sbspro.2013.08.430 